\title{
Effectiveness Using of Flipped Learning Strategy on Some Skillful Learning Aspects of Physical Education Lesson
}

\author{
Eman Abdel-Halim Mohamed ${ }^{1}$ \\ ${ }^{1}$ Faculty of Physical Education for Girls at Helwan University, Department of Curriculum and Teaching Methods of Physical \\ Education, Egypt
}

\begin{abstract}
The study aimed to learn some aspects of physical education lesson through using of flipped learning strategy. The researcher used the experimental method by experimental design of two groups (experimental and controlled group), the study was conducted on a sample of second division female students in faculty of physical education using pre-post measurements for each group on a sample of (60) female students with $14.78 \%$ of the total population (406 students) in the year 2017/2018, results indicated that using of flipped learning strategy led to a higher level of skillful learning under research (aspects of physical education lesson) compared to the explanation and presentation method.
\end{abstract}

Keywords: Strategy, Flipped learning, Skillful learning, P.E lesson.

\section{Introduction}

flipped learning is an instructional strategy and a
type of blended learning that reverses the
traditional learning environment by delivering
instructional content, often online, outside of the
classroom. It moves activities, including those that may
have traditionally been considered homework, into the
classroom. In a flipped learning, students watch online
lectures, collaborate in online discussions, or carry out
research at home while engaging in concepts in the
classroom with the guidance of a mentor. [31][35]

In the traditional model of classroom instruction, the teacher is typically the central focus of a lesson and the primary disseminator of information during the class period. The teacher responds to questions while students defer directly to the teacher for guidance and feedback. In a classroom with a traditional style of instruction, individual lessons may be focused on an explanation of content utilizing a lecture-style. Student engagement in the traditional model may be limited to activities in which students work independently or in small groups on an application task designed by the teacher. Class discussions are typically centered on the teacher, who controls the flow of the conversation.Typically, this pattern of teaching also involves giving students the task of reading from a textbook or practicing a concept by working on a problem set, for example, outside school. [34]
Flipped learning also redefine in-class activities. In-class lessons accompanying flipped learning may include activity learning or more traditional homework problems, among other practices, to engage students in the content. Class activities vary but may include: debate or speech presentation, current event discussions, peer reviewing, project-based learning, and skill development or concept practice [8][33] Because these types of active learning allow for highly differentiated instruction,[4] more time can be spent in class on higher-order thinking skills such as problem-finding, collaboration, design and problem solving as students tackle difficult problems, work in groups, research, and construct knowledge with the help of their teacher and peers.[11] Flipped learning hase been implemented in both schools and colleges and been found to have varying differences in the method of implementation.[4]

\section{Benefits of a Flipped Classroom}

There are various benefits attributed to the idea of utilizing the Flipped Classroom approach, some including:

1- A college reading empirical study identifies Flipped Classroom's approach at including all forms of learning (i.e. oral, visual, listening, hands on, problem solving, etc.).[23]

2- Rather than learning in a traditional classroom setting, Flipped Classroom uses a more application-based 
approach for students (i.e. hands on and problem solving activities).[13][32]

3- The accessibility of Flipped Classroom is extremely convenient, especially for students that would face difficulties in traveling to the physical classroom. Such students would still have the foundational information of the course at hand via online.[18]

4- Communication is greatly emphasized in a Flipped Classroom setting, essentially referring to: student-student and student-teacher interactions. [5]

5- Flipped Classroom utilizes a student-centered teaching modeled in order to ensure that the course is primarily aimed at contributing to the student's overall success in obtaining a proper, effective education. [5]

6- Essentially avoids the overarching idea of "cramming" for exams and forgetting the information postexamination, as it encourages students to understand the underlying rationale behind the information provided being provided to them.[30]

According to the above, this study is based offering content of lessons across the Internet through flipped learning strategy for the purpose of learning of skillful aspects in physical education lesson, The researcher observation during her work at the Faculty of Physical Education that Methods and means used to learn learning skillful aspects of physical education lesson lacks the motivation of the learner and the desire to learn more skills, as period after using these methods the learner sense monotony and boredom, these traditional methods doesn't commensurate with what the world reached of technological uses and applications in the educational process.

Thus, this research is based on the provide alternatives for teaching methods and content through this study (flipped learning strategy via the Internet) to find alternative paths for learners to learn and raise the educational process level.

\section{Reseach objective:}

The aim of this study was using of flipped learning strategy and monitor its effectiveness on learning of skillful aspects in physical education lesson for faculty of physical education female students.

\section{Reseach hypothesis:}

1- There are statistically significant differences between the average of the pre-and post-measurements for experimental group (flipped learning strategy group) in the level of learning skillful aspects under research in favor to the post measurement.

2- There are statistically significant differences between the average of the pre-and post-measurements of the controlled group (explanation and presentation group) in the level of learning skillful aspects under research in favor to the post measurement.

3- There are statistically significant differences in post measurements between the two experimental, controlled groups (flipped learning strategy, traditional method) in the level of learning skillful aspects under research in favor to the experimental group (flipped learning strategy).

\section{Methodology}

\section{Method:}

The experimental approach was used for two groups, one experimental and the other controlled, using pre- post measurements for each group.

\section{Research sample:}

The research society consisted of (406) female students of the second class students in faculty of physical education in Gezira - Helwan university for the academic year $2017 / 2018$. The basic sample was randomly selected from the female students of the research community. The total number of the sample was (60) female students with $14.78 \%$ of the total population, and the sample was divided as follows:

- Experimental group: uses flipped learning strategy in learn skillful aspects under research, (30) female students.

- Controlled group: uses the traditional method "explanation and presentation" in teach skillful aspects, (30) female students.

- (20) students of the total research community and outside the basic research sample as exploration sample. Thus, the basic sample and outside the basic research sample consisted of (80) female students by $19.70 \%$ of the total population.

\section{Tools:}

A. Data recording forms: Forms for recording the data for the research sample were prepared. (Appendix 1)

B. IQ test: Intelligence and mental abilities test was used, secondary and university stage verbal intelligence test, prepared by Gabir, Mahmoud (2007). (Appendix 2).[12] 
Table (1)

Validity and stability of IQ test

$\mathrm{N}=14$ (test validity), $\mathrm{N}=\mathbf{2 0}$ (test stability)

\begin{tabular}{|c|c|c|c|c|c|c|c|}
\hline \multirow[t]{2}{*}{ Variables } & \multirow[t]{2}{*}{ unit } & \multicolumn{2}{|c|}{$\begin{array}{c}\text { upper } \\
7=\mathrm{N} 1(33 \%)\end{array}$} & \multicolumn{2}{|c|}{$\begin{array}{c}\text { lower } \\
7=\mathrm{N} 2(33 \%)\end{array}$} & \multirow[t]{2}{*}{ Mean differences } & \multirow[t]{2}{*}{ T. value } \\
\hline & & $\mathbf{M}$ & \pm SD & $\mathbf{M}$ & \pm SD & & \\
\hline $\begin{array}{l}\text { Intelligence and mental } \\
\text { abilities }\end{array}$ & Degree & 90.84 & 1.99 & 85.61 & 1.84 & 5.23 & $3.22 *$ \\
\hline \multirow{2}{*}{ Variables } & \multirow{2}{*}{ unit } & \multicolumn{2}{|c|}{1 st } & \multicolumn{2}{|c|}{$2 \mathrm{n} . \mathrm{d}$} & \multirow{2}{*}{\multicolumn{2}{|c|}{$\mathrm{CC}$}} \\
\hline & & M & $\pm \mathrm{SD}$ & M & $\pm \mathrm{SD}$ & & \\
\hline $\begin{array}{l}\text { Intelligence and mental } \\
\text { abilities }\end{array}$ & Degree & 86.53 & 1.90 & 87.20 & 1.94 & \multicolumn{2}{|c|}{$0.940 *$} \\
\hline
\end{tabular}

The value of $t$-table at a significant level $(12,0.05)=2.18$ (two directions), the $t$-value $(\mathrm{cc})$ at a significant level $(18,0.05)=0.475$ (two directions).

It is clear from Table (1) that there are statistically significant differences between the two upper, lower groups in favor of the upper group, indicating the validity of the test. It is also evident that there is a correlation between the first and second applications indicating the stability of the test.

C. Evaluation form of skillful aspects (physical education lesson): The form was used evaluation of physical education lesson, prepared by Eman Abdel-Halim 2014 (Appendix 3).[9] The form was purposed to learn skillful aspects in physical education lesson for physical education female students. The form was prepared in 2014 through the following references: (Zeinab, Ghada 2010), (Abdallah
A., Rehab A. 2014), (Essam 2014), (Moustafa, Fathy 2002), (Zaghloul et al. 2001) and (Nawal, Mirvat 2002). [1][10][24][26][27][37]

The form was presented to the experts at the faculties of physical education (appendix 4) for the purpose of identifying the experts' opinion. The percentage of the experts' agreement was calculated on phrases of the form. The agreement rates on the phrases ranged from $75 \%$ to $100 \%$.

\section{Scientific transactions of the form:}


Table (2)

Validity of Internal Consistency of the form $(\mathrm{N}=20)$

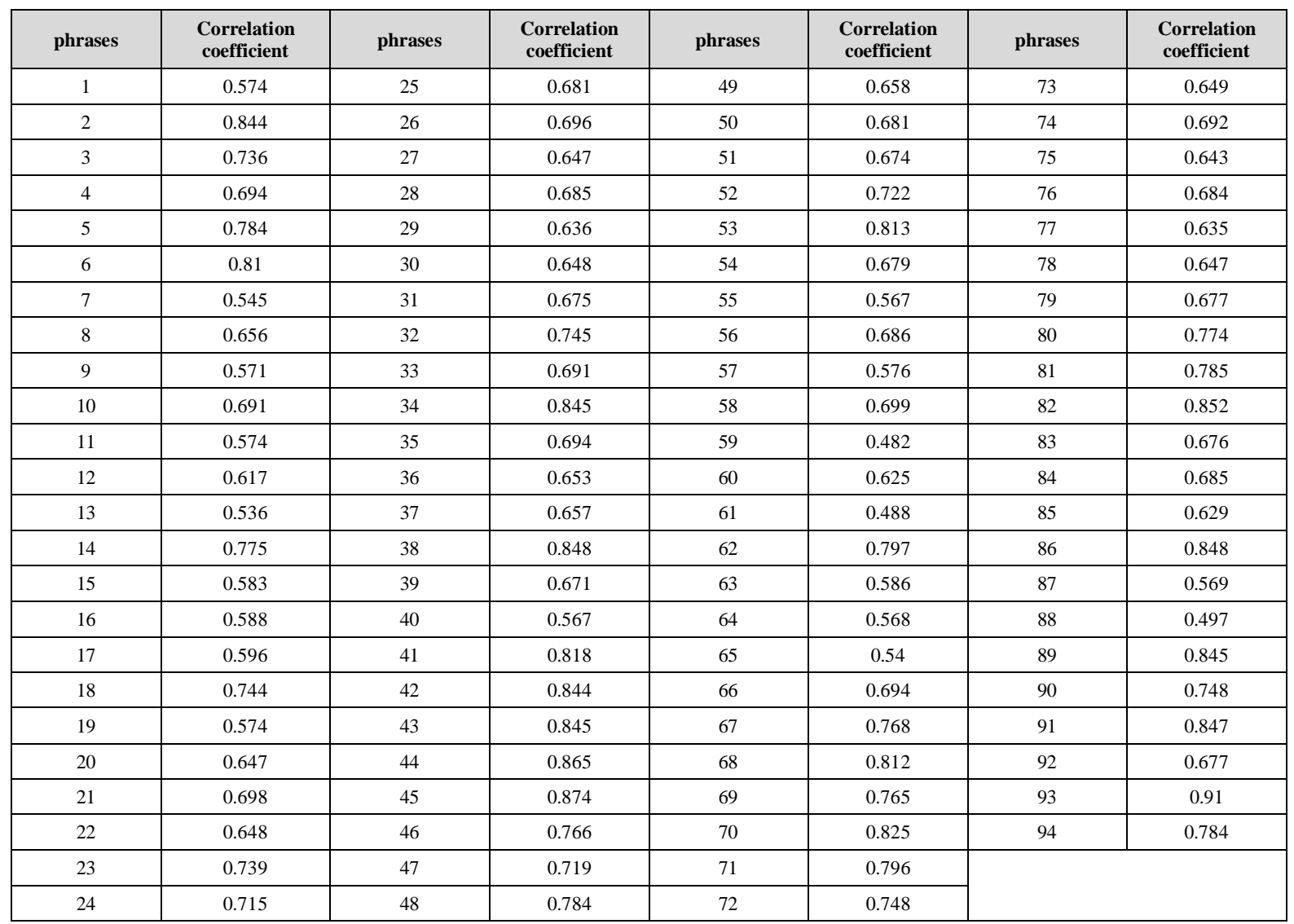

The t-value at a significant level $(18,0.05)=0.475$

It is clear from Table (2) that all the phrases has statistically significant greater than 0.475 and therefore was accepted all the terms and phrases of the form.

Table (3)

Stability of of the form $(\mathrm{N}=20)$

\begin{tabular}{|c|c|c|c|c|c|c|}
\hline \multirow{2}{*}{ Axis } & \multicolumn{2}{|c|}{ First half } & \multicolumn{2}{c|}{ Second half } & \multirow{2}{*}{ half - stability Coefficient } & \multirow{2}{*}{ Total stability coefficient } \\
\cline { 2 - 5 } & $\mathbf{M}$ & $\mathbf{\text { SD }}$ & $\mathbf{M}$ & $\mathbf{\pm S D}$ & 0.845 & 0.916 \\
\hline $\mathbf{1}$ & 20.66 & 4.38 & 20.48 & 4.4 & 0.837 & 0.911 \\
\hline $\mathbf{2}$ & 34.28 & 4.67 & 33.58 & 4.6 & 0.882 & 0.937 \\
\hline $\mathbf{3}$ & 3.25 & 0.04 & 3.64 & 0.48 & 0.864 & 0.927 \\
\hline Total & 54.67 & 4.44 & 53.41 & 4.28 & & \\
\hline
\end{tabular}

The $t$-value at a significant level $(18,0.05)=0.475$

- It is clear from Table (3) that there is a correlation between the first and second half, indicating the stability of the form.

- Thus, the form was applied on the basic research sample before and after the implementation of the educational units on the experimental and controlled group.

\section{Flipped learning strategy design:}

Flipped learning strategy was designed as shown below:

1- Objective of Flipped learning strategy: The flipped learning strategy was aimed to learn skillful aspects in physical education lesson for physical education female students. 
2- Mental and skillful level of the research sample: The mental aspect of the study sample was determined by Intelligence and mental abilities test (Appendix 2). The skillful aspect was determined by the evaluation form of physical education lesson. (Appendix 3).

3- Flipped learning strategy content: The flipped learning strategy content of the evaluation form of skillful aspects (physical education lesson) was determined through the following scientific references (Eman Abdel-Halim

Figure (1)

Model of flipped learning strategy site

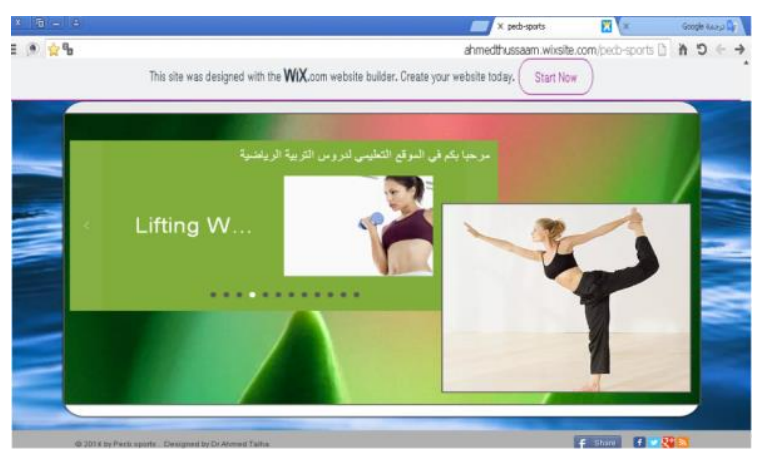

\section{Contents of physical education lesson, including the}

\section{following:}

- The introductory part of the lesson (including the preparation of physical education lesson, as well as the identification of the sections of the call, conditions and configurations of physical education lesson and how to prepare the tools, in addition to warm up and physical preparation and exercises).

- The main part of the lesson (including educational and practical activities).

- The final part of the lesson (including relaxation, greeting and departure).

4- Style of teaching in flipped learning strategy: The teaching style was used in the learn was the individual learning method through the use of each individual student for the Internet.

\section{5- Site features:}

- Display and download text, images, graphics and video on full screen.

- Sound control during video playback.

- Repetition of images, graphics and video more than once.
2014)[9], (Abdallah A., Rehab A. 2014)[1], (Zeinab, Ghada 2010)[37], (Essam 2014)[10], (Zaghloul et al. 2001)[24], (Nawal, Mirvat 2002)[27], (Moustafa, Fathy 2002)[26] by including some multimedia; videos, pictures and texts in A web site contains skillful aspects of physical education lesson, "http://ahmedthussaam.wixsite.com/pecb-sports", The site consists of the following contents:

- The main page.

- Pause during video playback.

\section{Some illustrations of the flipped learning strategy website:}
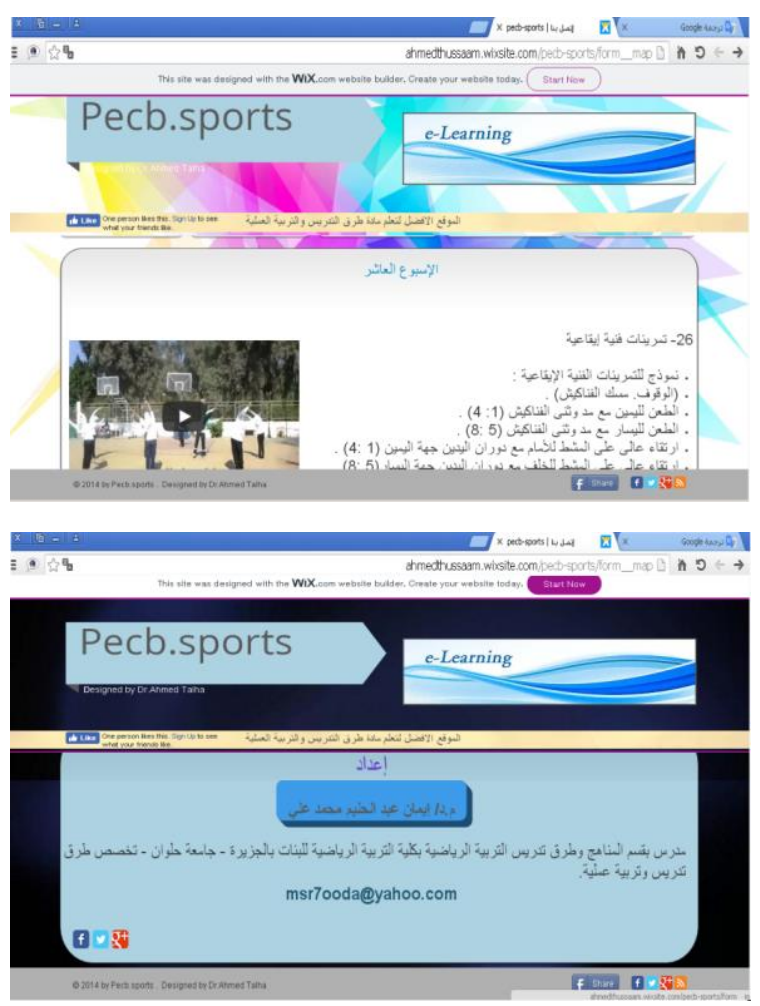

7- The experts' opinion (Appendix 4) of flipped learning strategy and agreement was obtained on a web site was designed, and the experts agreed to instructions and contents of the flipped learning strategy website (Appendix 5-A).

8- The exploratory study: The flipped learning strategy was tested by presenting the site on the sample of the exploratory study in order to identify the clarity of the pictures, drawings and video were flipped learning strategy contained on the website. The result of this 
experiment was the clarity of all the contents of the flipped learning strategy.

Distribution of the study content on the total units for two research groups:

The time distribution of the teaching unites was standardized for the two groups (experimental and traditional group), and the difference was only in the learning method for each group. The experimental group was learn by the flipped learning strategy via the website,
The controlled group was through explanation and presentation method. (Appendix 5-B)

\section{Application:}

Flipped learning strategy, traditional method (explanation and presentation) were implemented on the basic study sample, as shown in table (4), and as follow:

Table (4)

Time distribution of the two research groups

\begin{tabular}{|c|r|}
\hline Content & Time \\
\hline Program Duration & 10 weeks \\
\hline Number of units (lessons) per week & 2 units in week \\
\hline Unit Number & 20 units \\
\hline Unit time & $60 \mathrm{~m}$ \\
\hline
\end{tabular}

Flipped learning strategy, traditional method (explanation and presentation) were implemented as follow:

\section{A) Method of implementing flipped learning strategy:}

- First, the students seing the explanation, information, knowledge and educational videos of the skillful aspects of physical education lesson on the website (at home, for example).

- Students know through the educational site or through the researcher what is required preparation of the duties and tasks for the part to be implemented in college.

- The implementation of the students for what was seen in the lecture in college.

- The researcher observing the students' performance during the implementation of what was seen. The researcher correct for errors and provide feedback and adjust the performance of students.

B) Implementation of the traditional method (explanation and presentation):

- First, the researcher explain and present information, knowledge of the skillful aspects of physical education lesson.

- The implementation of the students for what has been explained and presented by the researcher in the lecture in college.

- The researcher observing the students' performance during the implementation of what was explained and presented. The researcher correct for errors and provide feedback and adjust the performance of students.

\section{Moderation of sample distribution:}

Table (5)

Distribution moderation for basic and exploratory research sample $(\mathrm{N}=80)$

\begin{tabular}{|c|c|c|c|c|c|}
\hline \multirow[b]{2}{*}{ Parameters } & \multirow[b]{2}{*}{ Unit } & \multicolumn{4}{|c|}{ Statistical analyses } \\
\hline & & Mean & \pm SD & Median & SK \\
\hline Age & year & 18.69 & 0.97 & 19.00 & -0.96 \\
\hline Intelligence & degree & 87.94 & 5.37 & 88.00 & -0.03 \\
\hline Evaluation form of skillful aspects & degree & 103.25 & 5.69 & 103.00 & 0.13 \\
\hline
\end{tabular}

Table (5) shows that the values of Skewness coefficients ranged from $\pm(3)$, indicating the moderated distribution of the basic and exploratory sample. 
Table (6)

Equivalence of the two research groups (tribal measurements) $(\mathrm{N}=60)$

\begin{tabular}{|c|c|c|c|c|c|c|}
\hline \multirow[t]{2}{*}{ Parameters } & \multicolumn{2}{|c|}{$\begin{array}{c}\text { Experimental } \\
30=\mathrm{N}\end{array}$} & \multicolumn{2}{|c|}{$\begin{array}{c}\text { Controlled } \\
30=\mathrm{N}\end{array}$} & \multirow{2}{*}{ Mean Differences } & \multirow[t]{2}{*}{$\mathbf{T}$} \\
\hline & $\mathbf{M}$ & $\mathrm{SD} \pm$ & $\mathbf{M}$ & $\mathrm{SD} \pm$ & & \\
\hline Intelligence & 87.95 & 5.33 & 87.92 & 5.31 & 0.03 & 0.67 \\
\hline Evaluation form of skillful aspects & 103.2 & 5.62 & 103.31 & 5.66 & 0.11 & 0.98 \\
\hline
\end{tabular}

T Table value at a significant level $(58,0.05)=2.01($ two directions $)$

Table (6) shows that all the values of the previous variables are not statistically significant, indicating that

Results there are no statistically significant differences and thus the equivalence of the two research groups.

Table (7)

Significance of the mean differences between the pre- post and post-post measurements of the two groups (experimental and controlled group) in skillful aspects (physical education lesson)

\begin{tabular}{|c|c|c|c|c|c|c|}
\hline \multirow{3}{*}{ Parameters } & \multicolumn{4}{|c|}{$\begin{array}{c}\text { Experimental } \\
\text { (flipped learning strategy) } \\
\mathrm{N} 30=1\end{array}$} & \multirow{3}{*}{ Mean Differences } & \multirow{3}{*}{ T value } \\
\hline & \multicolumn{2}{|c|}{ Pre } & \multicolumn{2}{|c|}{ Post } & & \\
\hline & M & SD \pm & $\mathbf{M}$ & $\mathrm{SD} \pm$ & & \\
\hline Evaluation form of skillful aspects & 103.20 & 5.62 & 201.38 & 15.67 & 98.18 & $37.58 *$ \\
\hline \multirow{3}{*}{ Parameters } & \multicolumn{4}{|c|}{$\begin{array}{c}\text { Controlled } \\
\text { (explanation and presentation) } \\
\mathrm{N} 30=2\end{array}$} & \multirow{3}{*}{ Mean Differences } & \multirow{3}{*}{$\mathrm{T}$ value } \\
\hline & \multicolumn{2}{|c|}{ Pre } & \multicolumn{2}{|c|}{ Post } & & \\
\hline & M & $\mathrm{SD} \pm$ & M & $\mathrm{SD} \pm$ & & \\
\hline Evaluation form of skillful aspects & 103.31 & 5.66 & 192.58 & 14.28 & 89.27 & $32.53 *$ \\
\hline \multirow{3}{*}{ Parameters } & \multicolumn{4}{|c|}{$\begin{array}{c}\text { Post } \\
\text { N60 }\end{array}$} & \multirow{3}{*}{ Mean Differences } & \multirow{3}{*}{$\mathrm{T}$ value } \\
\hline & \multicolumn{2}{|c|}{ Experimental } & \multicolumn{2}{|c|}{ Controlled } & & \\
\hline & $\mathrm{M}$ & $\mathrm{SD} \pm$ & M & $\mathrm{SD} \pm$ & & \\
\hline Evaluation form of skillful aspects & 201.38 & 15.67 & 192.58 & 14.28 & 8.80 & $12.58^{*}$ \\
\hline
\end{tabular}

T Table value at a significant level $(29,0.05)=1.70$ (one direction)

$T$ Table value at a significant level $(58,0.05)=1.67$ (one direction)

Table (7) shows statistically significant differences between Pre-Post measurements of both experimental and controlled groups, as well as in post measurements between the two groups at a significant level of 0.05 .

\section{Discussion}

\section{First research hypotheses:}

The results of Table (7) show that there are statistically significant differences between pre and post mean values of the experimental group in learn skillful aspects in favor to the post measurement.
These results indicate that the flipped learning strategy via the website was a positive effect on the skillful level under research (skillful aspects). This indicates that the flipped learning strategy led to the correct perception of how to perform and element physical education lesson. The images, drawings, texts and videos were attached to the educational site was a positive result on the learning process, which is how to emplement the introductory, the main and the final part in physical education lesson

The previous results is consistent with many studies which was indicated that use of the flipped learning strategy in the educational process shows an improvement and effectiveness in the learning process in general, such as the 
study of (Al-Zahrani 2015), (Turner, and Meyer 2009), (Lage, Platt, \& Treglia 2010). [2][19][28]

Thus, the researcher attributed the reason of differences between pre and post measurements to the experimental variable only, which is the flipped learning strategy via the Internet. The researcher also attributes the progress in learning the skillful aspects under research to relying on the flipped learning strategy and its various media (texts, pictures, graphics, audio and video) and thus a positive effect on variables of research (physical education lesson) and this is due to the attractiveness and effectiveness of flipped learning strategy via the Internet.

Thus, the first hypothesis is achieved, which stated that there are statistically significant differences between the pre-and post-measurements for experimental group (flipped learning strategy group) in the learn level of skillful aspects under research in favor to the post measurement.

\section{Second research hypotheses:}

The results of Table (7) show that there are statistically significant differences between pre and post mean values of the controlled group in learn skillful aspects in favor to the post measurement.

These results indicate that the explanation and presentation method was a positive effect on learn of the skillful aspects under research. This indicates that the traditional method of teaching was led to students improvement in the information and concepts related to these parts (introductory, main and final part) of the lesson. Thus, Improved and effective learning in emplement of physical education lesson.

The previous results was indicated that the method of explanation and presentation leads to progress and improvement in the educational process, where the teacher relied on the explane of information and content understanding of the performance through verbal explanation and a model presentation of how to implement and this was led to effectiveness and positive on implement of physical education lesson for the controlled group. This is consistent with Zakia Kamel, Nawal Shaltout and Mervat Khafaja (2010)[36] where they pointed out that the method of explanation and presentation has a positive effect on the learning of skills under research.

Accordingly, This proves that teaching through explanation and presentation leads to higher level of learning and performance as a result of the practice of what has been explained and presented by the teacher.
Thus, reflected in the level of students' performance during the learning process.

This indicates that the method of explanation and presentation was led to the effectiveness and positive in the educational process according to the results of statistically significant differences between pre and post measurement.

Therefore, the second hypothesis is achieved, which stated that there are statistically significant differences between the pre-and post-measurements for the controlled group (explanation and presentation group) in the learn level of skillful aspects under research in favor to the post measurement.

\section{Third research hypotheses:}

The results of Table (7) show that there are statistically significant differences in post mean values between the two groups (experimental, controlled) in the level of learn skillful aspects, where the value of calculated (t) (12.58) is greater than the value of table $(\mathrm{t})$ at a significant level (0.05), which indicates the higher level of learn for the experimental group (flipped learning strategy) than the controlled group (explanation and presentation).

The researcher attributes the progress of the experimental group compared to the controlled group to the interaction between the student and the learning through the flipped learning strategy via the internet which the students controlled what they are subjected to and controlled the sequence of the presentation, time, in addition to the formation of the optimal perception of the performance of skillful in how to emplement the skillful aspects in physical education lesson. Thus, provide the student feedback, which was helped to develop his movement perception, This is not available to students of the controlled group. Therefore, the effectiveness of flipped learning strategy via the website compared to the explanation and presentation method. This is in line with Mohamed Sarhan, Al-Tayeb Haroun (2015)[25], Marcey, DJ, \& Brint (2012)[21] that using flipped learning allows students to spend more time learning and pre-preparing to parts of the lesson by watching recorded video In advance, and this gives sufficient time to prepare the parts of the physical education lesson and allow more time for application in the college (lecture) rather than explanation. Thus, acquire and refine and develop skillful aspects under research (implementation of physical education lesson parts), which ensures the good use of the time of the lecture practical.

This proves that using flipped learning strategy has a positive effect on emplement of physical education lesson, 
because of the attractiveness and effectiveness of using the flipped learning via the site. Thus, increase the element of suspense and tendency towards learning by students' interests raising and motivate them to exert effort compared to the traditional method in teaching which did not have these characteristics, which led to the effectiveness and positive learning through using flipped learning strategy via the internet compared to the method of explanation and presentation.

The above is consistent with the study both of Chastre, Edouard (2015)[16], which indicated that the using of multimedia and technology in general in the educational process has effective in learning the skills under research because of the attractiveness and effectiveness of multimedia e-studies compared to others traditional methods.

Thus, it is clear from the above that flipped learning strategy using the Internet has a positive effect on the skillful aspects of physical education lesson compared to the controlled group, and this is consistent with the study results: (Atkins 2013), (Jaster 2013), (Johnson \& Renner 2016) which have pointed out that the using the flipped learning strategy leads to learning of different skills in a positive way compared to explanation and presentation method. [6][15][17]

Therefore, the third hypothesis is achieved, which stated that there are statistically significant differences in post measurements between the experimental and controlled groups for the learn level of skillful aspects under research in physical education lesson in favor to the experimental group (flipped learning strategy).

\section{Conclusions}

1- Flipped learning strategy using the Internet, explanation and presentation method have effective on learning skillful aspects in physical education lesson (introductory, main and final part of the lesson).

2- Flipped learning strategy via the Internet has a more effective effect on learning killful aspects of physical education lesson compared to the traditional method in teaching (explanation and presentation method).

\section{Recommendations}

1- Encouraging the using flipped learning strategy because of its positive effect in learn skillful aspects of physical education lesson.
2- Introducing learning through flipped learning strategy within the curricula of the scientific subjects in the faculties of physical education.

3- Conducting further studies on the effectiveness of flipped learning strategy through the internet in other cognitive and skillful aspects.

\section{References}

1- Abdallah Abdel-Halim Mohamed, Rehab Adel Gabal: Teaching in the light of the contemporary reality of sports education (concepts, principles, applications), World Sports Foundation for publishing and Dar Al-Wafaa for printing, 3rd, Alexandria 2014.

2- Abdel-Rahman Mohamed Al-Zahrani: "Effectiveness of the strategy of the inverted row in the development of the cognitive achievement level of the e-learning course of the Faculty of Education students, King Abdulaziz University, Education Faculty Journal, Al-Azhar University, 2015.

3- Abeysekera, Lakmal, and Phillip Dawson: "Motivation and cognitive load in the flipped classroom: definition, rationale and a call for research." Higher Education Research \& Development 34(1), 1-14, 2015.

4- Alvarez, B.: "Flipping the classroom, Homework in class, lessons at home". Education Digest: Essential Readings Condensed For Quick Review, 77 (8): 18-21, 2011.

5- Aşıksoy G., Özdamlı F.: "Flipped Classroom adapted to the ARCS Model of Motivation and applied to a Physics Course".Eurasia Journal of Mathematics. 12: 1589-1603 via EJMSTE, June 2016.

6- Atkins, A.B.: Turning education on its head: A study of effectiveness and student satisfaction in the flipped high school classroom. (Master's thesis). Salem College, Winston-Salem, NC, 2013.

7- Baker, J.W.: "The 'Classroom Flip", Using Web course management tools to become the Guide by the Side." In J. A. Chambers (Ed.), Selected papers from the 11th International Conference on College Teaching and Learning, pp. 9-17. Jacksonville, FL: Florida Community College at Jacksonville, 2010.

8- Bergmann, J., \& Sams, A.: Flip your classroom, reach every student in every class every day, ISBN 1564843157 , Washington, DC: International Society for Technology in Education, 2012.

9- Eman Abdel-Halim Mohamed: "Program design using multimedia and its impact on the outcomes of practical 
teaching methods learning course for students of the Faculty of Physical Education" unpublished doctoral thesis, Faculty of Physical Education in Gezera, Helwan University 2014.

10- Essam El-Din Metwally Abdallah: Methods of teaching physical education between theory and practice, the world of sports publishing and Dar Al-Wafa for printing, Alexandria 2014.

11- Foertsch, Julie, Bennett, B., Spencer, D., Bergmann, J., Cockrum, T., Musallam, R., Sams, A., Fisch, K., \& Overmyer, J.: "The flipped classroom manifest" \& "Reversing the Lecture/Homework Paradigm Using eTEACH® Web-based Streaming Video Software." Journal of Engineering Education 91.3 (2002): 267-274, 2013.

12- Gabir Abdel-Hamid Gabir, Mahmoud Ahmed Omar: Linguistic intelligence Test of secondary and university stage, Dar al-Nahda Arab, p.1-13, Cairo 2007.

13- Glynn, James: "The Effects of a Flipped Classroom on Achievement and Student Attitudes in Secondary Chemistry" (PDF).Montana State University, July 2013.

14- Greg Topp: "Flipped classrooms take advantage of technology", USA Today, 6 Oct 2011.

15- Jaster, R.W.: Inverting the classroom in college algebra: An examination of student perceptions and engagement and their effects on grade outcomes. (Doctoral dissertation, Texas State University-San Marcos). Retrieved from https://digital.library.txstate.edu/handle/10877/4526, 2013.

16- Jean Chastre, Charles-Edouard: Factors affecting the e-learning outcomes, Telematics and Informatics, Volume 32, Issue 4, November 2015, Pages 701-719.

17- Johnson, L., \& Renner. J.: Effect of the flipped classroom model on a secondary computer applications course: Student and teacher perceptions, questions and student achievement. (Doctoral dissertation, University of Louisville.), 2012.

18- Kettle, Maria: "Flipped Physics". Physics Education. 48: 593-596 - via EBSCO, 2013.

19- Lage, M.J., Platt, G. \& Treglia, M.: Inverting the classroom: A gateway to creating an inclusive learning environment. The Journal of Economic Education, 31 (1), 30-43, 2010.

20- Luttenberger, Silke; Macher, Daniel; Maidl, Verena; Rominger, Christian; Aydin, Nilüfer; Paechter, Manuela: "Different patterns of university students' integration of lecture podcasts, learning materials, and lecture attendance in a psychology course", 2017.

21- Marcey, D. J., \& Brint, M. E: Transforming an undergraduate introductory biology course through cinematic lectures and inverted classes: A preliminary assessment of the CLIC model of the flipped classroom. In Biology Education Research Symposium at the Annual Meeting of the National Association of Biology Teachers. (Vol. 12), 2012.

22- Marco Ronchetti: "Using video lectures to make teaching more interactive", International Journal of Emerging Technologies in Learning (iJET), June 2010.

23- Mo, Jun, Mao, Chunmei: "An Empirical Study on the Effectiveness of College English Reading Classroom Teaching in the Flipped Classroom Paradigm". Revista de la Facultad de Ingeniería U.C.V. 32: 632-639 - via PKP, 2017.

24- Mohamed Saad Zaghloul, Makarem Helmi Abu Harja, Radwan Mohamed Radwan: Encyclopedia of Field Training in Physical Education, Book Center, Cairo 2001.

25- Mohamed Sarhan, Al-Tayeb Hassan Haroun: "Effect of the Inverted Learning Model Effectiveness on the Achievement and Performance of E-Learning Skills of Undergraduate Students in the Faculty of Education". The First International Conference of the College of Education (Education Future Horizons), April 2015.

26- Moustafa El-Sayeh Mohamed, Fathy El-Kordany: Practical Education between Theory and Practice, University House, Alexandria, 2002.

27- Nawal Ibrahim Shaltout, Mirvat Ali Khafaja: Teaching methods in physical education "Teaching and Learning" Part II, Al-Eshaa library, Alexandria 2002.

28- Perry, N., Turner, J., \& Meyer, D.: Classrooms as contexts for motivating learning. In P.A. Alexander and P.H. Winne (Eds.), Handbook of Educational Psychology. (pp. 327-348), New York: NY: Routledge, 2009.

29- Rosenberg, Tina: "In 'Flipped' Classrooms, a Method for Mastery". New York Times, 2013. The Flipped Learning Global Initiative. Retrieved 2 August 2016.

30- Rotellar PharmD, Cristina, Cain EdD, MS, Jeff: "Research, Perspectives, and Recommendations on Implementing the Flipped Classroom". American Journal of Pharmaceutical Education.80 - via NCBI, 25 Mar 2016.

31- Ryback, D., \& Sanders, J.: Humanistic versus traditional teaching styles and student satisfaction. Journal of Humanistic Psychology, 20(87), 87-90, 2008. 
32- Sharma, Neel, Lau, C.S, Doherty, Iain, Harbutt, Darren: "How we flipped the medical classroom". Medical Teacher. 37: 327-330 - via EBSCO, April 2015.

35- Wikipedia: Article about Flipped classroom at https://en.wikipedia.org/wiki/Flipped_classroom, 29 April 2017.

33- Sparks, S.

["http://www.edweek.org/ew/articles/2011/09/28/05khan_ ep.h31.html, Schools "flip" for lesson model promoted by Khan Academy"].Education Week, 31 (5): 1, 2011.

34- Strauss, Valerie: "The flip: Turning a classroom upside down". Washington Post, 3 June 2012. methods of physical education "theoretical foundations
D: 36- Zakia Ibrahim Kamel, Nawal Ibrahim Shaltout, Mervat Ali Khafaja: Fundamentals of Teaching Physical Education, Technical Radiation Press (Al-eshaa Press), 2nd edition, Alexandria 2010.

37- Zeinab Ali Omar, Ghada Galal Abdulhakim: Teaching and practical applications" Arab Thought House, Cairo 2010 . 